\title{
Glycolytic enzyme inhibitory and antiglycation potential of Gymnema sylvestre R. Br.: An in silico approach
}

\author{
K. Kamalakkannan , N. Kiruthiga, V. Balakrishnan*, T. Sivakumar, G. Liji Martina**, M. Janani** and S. Ramya*** \\ Department of Biotechnology, Nandha College of Pharmacy, Erode-638052, Tamilnadu, India \\ *Department of Botany, Arignar Anna Govt. Arts College, Namakkal-637002, Tamilnadu, India \\ **Nandha College of Physiotherapy, Erode-638052, Tamilnadu, India \\ ***Nandha College of Nursing, Erode-638052, Tamilnadu, India
}

\section{Article Info}

\section{Article history}

Received 17 October 2021

Revised 6 December 2021

Accepted 7 December 2021

Published Online 30 December 2021

\section{Keywords}

R. Dr. Gymnema sylvestre

Protein glycation

Inhibitory enzyme

Docking

Diabetes mellitus

\begin{abstract}
Traditional herbal medicines are practiced worldwide for treatment of type II diabetes mellitus since ancient times. Gymnema sylvestre R. Br. has been used in ayurvedic medicine for the treatment of diabetes. Our target was to investigate the $\alpha$-amylase, $\alpha$-glucosidase and aldose reductase inhibitory along with antiglycation potential of methanolic extract of $G$. sylvestre and molecular docking of dihydroxy gimnemic triacetate. The enzyme inhibitory study revealed that $G$. sylvestre showed prominent $\alpha$-amylase, $\alpha$-glucosidase and aldose reductase inhibitory potential $(42.49 \%, 47.21 \%$ and $38.93 \%)$ at concentration $200 \mu \mathrm{g} / \mathrm{ml}$, respectively. In glycation inhibitory activity, fructosamine inhibitory potential was found to be $36.22 \%$, protein carbonyls were inhibited up to $15.56 \%$ whereas protein thiols were inhibited up to $67.84 \%$. It shows, $G$. sylvestre significantly inhibited $(p<0.001)$ activity of $\alpha$-amylase, $\alpha$-glucosidase and aldose reductase. The interaction of dihydroxy $G$. triacetate with these enzymes were validated by docking studies. The docking study showed the remarkable binding of $\alpha$-amylase, $\alpha$-glucosidase and aldose reductase with Dihydroxy G. Triacetate. Molecular docking study, which can be concluded that the phytochemicals have enhanced binding sites, interactions and potent inhibitory effect on enzyme activity. The results indicate that the significant antidiabetic properties of these G. sylvestre and its phytochemicals may attribute to its $\alpha$-amylase, $\alpha$-glucosidase and aldose reductase.
\end{abstract}

\section{Introduction}

Herbal plants have been utilized to cure a variety of diseases around the world before the arrival of contemporary clinical medications, and they are known to contain chemicals that can be employed for therapeutic purposes or as precursors for the production of beneficial drugs (Sofowora, 1982). As a result, natural products account for more than half of all modern medications, and they play an essential role in drug discovery in the pharmaceutical business (Jeyachandran and Mahesh, 2007). Traditional herbal medicines are practiced worldwide for treatment of type II diabetes mellitus since ancient times. The traditional medicines are mainly used which are obtained from plants, it plays important role in the management of diabetes mellitus (Patel and Srinivasan, 1997).

G. sylvestre (Asclepiadaceae) is a large tropical liane native to central and western India and can be also found in tropical Africa and in Australia (Stocklin, 1969). G. sylvestre is a popular antidiabetic herb. There is a growing demand for G. sylvestre leaves in pharmaceutical trade (Tiwari et al., 2013). The blood sugar lowering activity of Gymnema leaves was first documented in the late 1920s (Mhasker and Caius, 1930). dihydroxy gimnemic Triacetate, the main active

Corresponding author: Dr. K. Kamalakkannan

Professor, Department of Biotechnology, Nandha College of Pharmacy Erode-638052, Tamilnadu, India

E-mail: car2203@gmail.com

Tel.: +91-9789502934

Copyright (c) 2021 Ukaaz Publications. All rights reserved.

Email: ukaaz@yahoo.com; Website: www.ukaazpublications.com ingredient of this plant, is used widely as an antidiabetic (Shanmugasundaram et al., 1983), antisweetner (Kurihara, 1992) and antihypercholesterolemia (Bishayee and Chatterjee, 1994). It also has stomachic, diuretic and cough suppres-sant properties (Kapoor, 1990).

Diabetic mellitus is a disorder of carbohydrate and lipid metabolism in the cell. The condition is linked to a decreased quality of life as well as increased mortality and morbidity risk factors. Long-term hyperglycemia is a significant contributor to the onset and progression of micro and macrovascular problems (Strojek, 2003). Overproduction of ROS in endothelial cells of both big and small arteries has been linked to metabolic problems in diabetic patients. The aetiology of diabetes problems such as neuropathy, nephropathy, and retinopathy is hypothesised to be influenced by an imbalance in ROS (Wada and Ou, 2002; Genet et al., 2002).

The enzymes involved in the breakdown of polysaccharides which have shown have remarkable results in order to control blood glucose level in type II diabetes mellitus (Kim et al., 2005; Mai and Chuyen, 2007; Davis and Granner, 1996). $\alpha$-amylase is one of the most important enzymes in this process, as it catalyses the breakdown of starch into maltose, which is then transformed to glucose, which is the only sugar that the body can use (Kotowaroo et al., 2006; Neerja et al., 2017). Another crucial enzyme to be aware of is intestinal $\alpha$ glucosidase, which is found in the epithelium of the small intestine. The key enzyme aldose reductase, which is the first and rate-limiting enzyme in the polyol pathway, is involved in the conversion of 
glucose to sorbitol. In diabetics, prolonged hyperglycemia causes the development of sorbitol in insulin-insensitive tissues like the lens, retina, nerves, and kidneys via the polyol pathway (Ueda et $a l ., 2001)$. These enzymes are now regarded as a therapeutic target for the modulation abnormality that occurs in type II diabetic mellitus (Yao et al., 2010; Lalitha and Sivakumar, 2018).

To explore ligand conformations within acromolecular targets' binding sites, molecular docking methods are commonly used in current drug design. This method determines the ligand-receptor binding free energy by analysing key events in the intermolecular recognition process. Given the large range of docking methods available today, knowing the advantages and disadvantages of each method is crucial for developing effective strategies and producing relevant results. When compared to experimental techniques like HTS, molecular docking has a number of advantages, one of which is its ability to screen large compound databases at a low cost (Acharya et al., 2011).

Hence, the present study was to investigate the $\alpha$-amylase, $\alpha$ glucosidase and aldose reductase inhibitory along with antiglycation potential of methanolic extract of G. sylvestre and molecular docking of dihydroxy gimnemic triacetate.

\section{Materials and Methods}

\subsection{Extraction procedure}

G. sylvestre leaves were collected in and around Erode, Tamilnadu in June 2019, and the plant was validated by the Botanical Survey of India (BSI) in Coimbatore. The samples were air dried at room temperature. Dried leaves ( $200 \mathrm{~g}$ ) were coarsely crushed and subjected to continuous hot extraction followed by sequential solvent extraction (Soxhlet). Methanol was used for the extraction. The marc was air dried each time. The extract was concentrated using a rotary flash evaporator to evaporate the solvent. The extract was maintained in sealed containers at $4{ }^{\circ} \mathrm{C}$ until it was needed (David and Sudarsanam, 2013).

\subsection{Glycolytic enzyme inhibition studies}

\subsection{1 $\alpha$-amylase inhibitory assay}

The reducing sugar (maltose equivalent) liberated under the assay conditions was used to determine $\alpha$-amylase inhibition. The inhibitory activity of the enzyme was measured as a reduction in the amount of maltose released. To calculate the maltose equivalent, a modified dinitrosalicylic acid (DNS) technique was used. $1 \mathrm{ml}$ of the methanolic extract of $G$. sylvestre plant was pre-incubated with $\alpha$-amylase. $1 \mathrm{U} /$ $\mathrm{ml}$ for $30 \mathrm{~min}$ and thereafter $1 \mathrm{ml}(1 \% \mathrm{w} / \mathrm{v})$ starch solution was added. The mixture was further incubated at $37^{\circ} \mathrm{C}$ for $10 \mathrm{~min}$. After stopping the reaction, using $1 \mathrm{ml}$ dinitrosalicylic acid reagent, the contents were heated in a boiling water bath for $5 \mathrm{~min}$. At $540 \mathrm{~nm}$, the absorbance was determined. Voglibose was used as positive control (Puratchimani and Jha, 2004). The antidiabetic activity, which was computed using the following equations:

$$
\begin{aligned}
\% \text { reaction } & =(\text { Maltose }) \text { test } /(\text { Maltose }) \text { control } \times 100 \% \text { inhibition } \\
& =100 \% \text { reaction }
\end{aligned}
$$

\subsection{2 $\alpha$-glucosidase inhibitory activity}

The $\alpha$-glucosidase inhibitory activity was determined using the standard method (Sutedja, 2005: Nupur et al., 2019). $0.5 \mathrm{mg}$ glucosidase was dissolved in $10 \mathrm{ml}$ phosphate buffer and $10 \mathrm{mg}$ bovine serum albumin to make the enzyme solution. DMSO was used to make sample solutions with various concentrations $(25,50$, $75,100,125,150,175,200 \mathrm{~g} / \mathrm{ml}$ ), and $5 \mu 1$ of each sample solution or DMSO (sample blank) was added to $200 \mu \mathrm{l}$ of $20 \mathrm{mM}$ p-nitrophenyl d-glucopyranoside and $480 \mu \mathrm{l}$ of $100 \mathrm{mM}$ phosphate buffer $(\mathrm{pH}$ 7.0). It was pre-incubated for $5 \mathrm{~min}$ at $37^{\circ} \mathrm{C}$ before the reaction began with the addition of the enzyme solution, which was then incubated for exactly $15 \mathrm{~min}$ at $37^{\circ} \mathrm{C}$. The reaction was then halted by adding $1000 \mu \mathrm{l}$ of $200 \mathrm{mM} \mathrm{Na}_{2} \mathrm{CO}_{3}$ solution, and the amount of p-nitrophenol released was determined using a UV-visible spectrophotometer by comparing the absorbance of the sample to that of a blank at $400 \mathrm{~nm}$.

\subsubsection{Aldose reductase inhibitory activity}

Aldose reductase activity was assayed according to the method described by Haraguchi et al. 1997. Using glyceraldehyde as a substrate, the oxidation of NADPH at $340 \mathrm{~nm}$ was monitored spectrophotometrically at room temperature to evaluate enzyme activity. Various concentrations $(25-200 \mu \mathrm{g} / \mathrm{ml})$ of alcoholic extract of $G$. sylvestre were added to assay mixtures of aldose reductase and incubated for $5 \mathrm{~min}$ before initiating the reaction by NADPH. The percentage inhibition was calculated considering the activity in the absence of methanolic extract of G. sylvestre as $100 \%$. Linear regression analysis of the plot of percentage inhibition versus concentration yielded the half-maximal inhibitory concentration values.

\subsubsection{Antiglycation potential}

Albumin glycation was performed with certain modifications. Glycated BSA samples were made and kept in sealed tubes at $37^{\circ} \mathrm{C}$ for 4 consecutive days. In the same way, a positive control was maintained. Triplicates of each incubate were created. The solution's unbound form of fructose was kept at $4^{\circ} \mathrm{C}$. The resulting was utilised to estimate fructosamine adducts, protein carbonyls, protein thiols, and Congo red absorbance to determine the extract's antiglycation activity (McPherson et al., 1988; Kiruthiga et al., 2021).

\subsubsection{Estimation of fructosamine}

Fructosamine was measured using the nitrobluetetrazolium assay (Baker et al., 1994). The aliquots of glycated samples and positive control were incubated at $37^{\circ} \mathrm{C}$ for $30 \mathrm{~min}$ with $0.6 \mathrm{ml}$ of nitro blue tetrazolium in sodium carbonate buffer. The absorbance at $530 \mathrm{~nm}$ was measured after incubation, and the \% inhibition of fructosamines by extract was determined using the formula below.

$$
\text { Inhibitory activity }(\%)=\left[\left(\mathrm{A}_{0}-\mathrm{A}_{1}\right) / \mathrm{A}_{0}\right] \times 100
$$

\subsubsection{Carbonyl group estimation}

The concentration of protein carbonyls was determined using the molar extinction coefficient and absorbance at $360 \mathrm{~nm}$ (Uchida et al., 1998). The results were expressed as a percentage inhibition, which was computed using the fructosamine estimation procedure.

\subsubsection{Protein thiol estimation}

Dithionitrobenzoic acid was used to determine the thiol groups of glycated albumin and a positive control (Ellman, 1959). In this test, $260 \mu \mathrm{l}$ samples and controls were incubated for $15 \mathrm{~min}$ with three volumes of DTNB before the absorbance was measured at $400 \mathrm{~nm}$. The standard curve of varied BSA concentrations was used to calculate 
the free thiol concentration in the solution. The formula employed in the estimation of fructosamine was utilized to calculate the \% protection.

\subsubsection{Binding of congo red}

Congo red binding was measured by taking the absorbance at $530 \mathrm{~nm}$ (Klunk et al., 1999). For this assay, the samples $(500 \mu 1)$ were incubated with $100 \mu \mathrm{l}$ of congo red $(100 \mu \mathrm{M})$ in phosphate buffered saline with $10 \%(\mathrm{v} / \mathrm{v})$ ethanol for $20 \mathrm{~min}$ at room temperature.

\subsection{Docking studies}

Molecular docking was performed on dihydroxy gimnemic triacetate, which is notable active principle present in G. sylvestre. A Lamarckian genetic algorithm method implemented in the program AutoDock 4.2 was used to study the molecular interactions between the phytochemical ligands such as dihydroxy gimnemic triacetate against the enzyme $\alpha$-amylase, $\alpha$-glucosidase and aldose reductase. Auto dock tools were used to study the docking simulations (trott and olson, 2010; Selvaraj et al., 2014). Auto dock relies on pre-calculated grid maps, one for each type of atom in the flexible molecules to be docked. To perform docking calculations, gasteigere-marsili partial charges were applied to the ligands, non-polar hydrogen atoms were merged, and all torsions were allowed to be tested using Bonferroni's test $(* p<0.001)$. The interactions and binding energy of the docked structure were investigated using the auto dock data.

\subsection{Statistical analysis}

The results are expressed as mean \pm standard error of mean. Experiments were always carried out in three different ways. The analysis of variance was used to compare the two groups, followed by the Bonferroni test $(p<0.001)$.

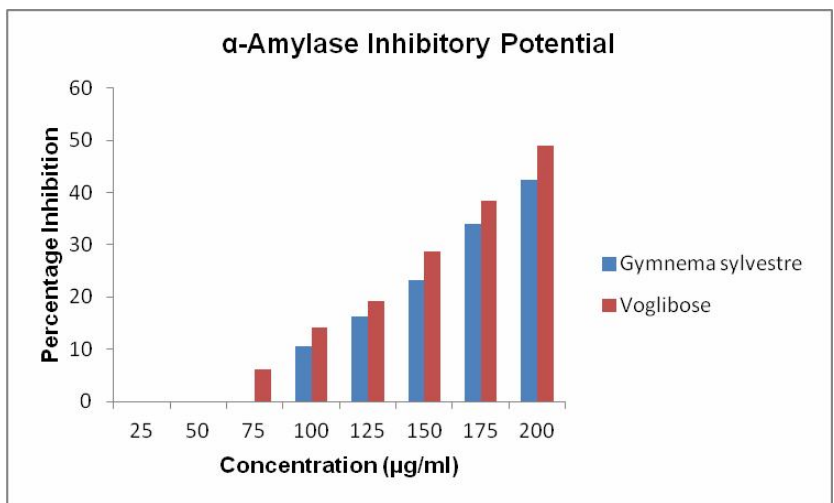

Figure 1: Inhibitory potential of $G$. sylvestre against $\alpha$-amylase.

\section{Results}

The present study was to establish the inhibitory activity of G. sylvestre against $\alpha$-amylase, $\alpha$-glucosidase and aldose reductase. The Figure 1, shown the inhibitory potential activity of methanolic extract of G. sylvestre, which justifies that G. sylvestre showed prominent $\alpha$-amylase inhibitory potential $(42.49 \%$ at concentration $200 \mu \mathrm{g} / \mathrm{ml}$ ). This percentage of inhibition ranged from 10.36 to 42.49 $\%$. The $\alpha$-glucosidase inhibitory activity of $G$. sylvestre is shown in Figure 2. For all tested concentrations, percent $\alpha$-glucosidase inhibition increased with increasing concentration of $G$. sylvestre.
Inhibition in enzyme activity ranged from 11.05 to $47.21 \%$. Aldose reductase reveal the range from 8.16 to $38.93 \%$ is shown in Figure 3. In the presence of the extract, the inhibitory activities of $\alpha$-amylase, $\alpha$-glucosidase and aldose reductase enzymes significantly rise, according to statistical analysis.

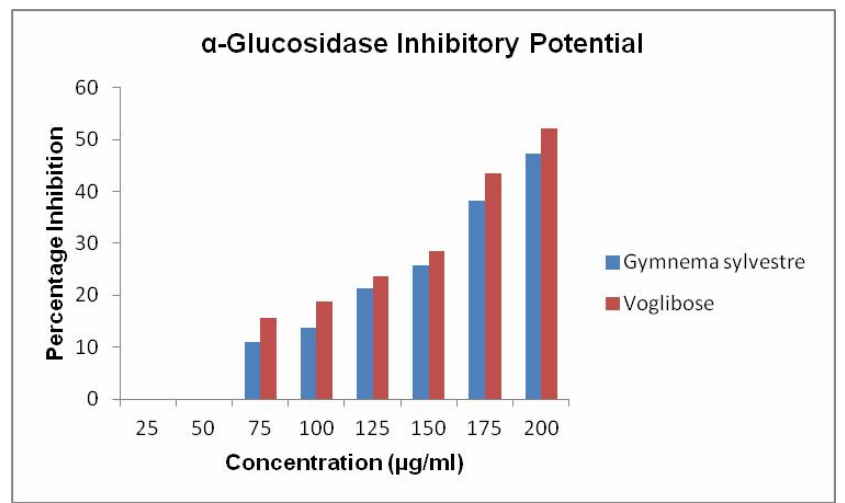

Figure 2: Inhibitory potential of $G$. sylvestre against $\alpha$ glucosidase.

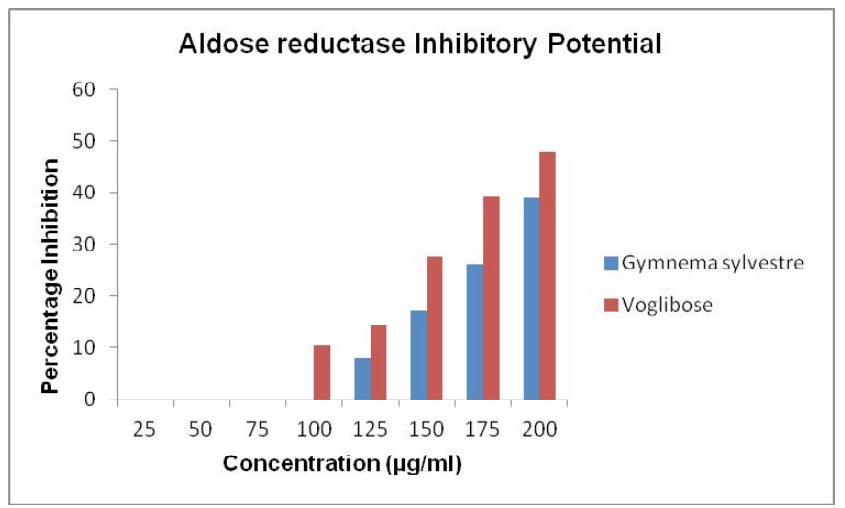

Figure 3: Inhibitory potential of G. sylvestre against aldose reductase.

The results on glycation inhibitory activity of G. sylvestre, a naturally occurring the therapeutic value of medicinal herbs which was already proven to an antidiabetic, was done using an in vitro glucose-bovine serum albumin (BSA) assay. Glucose and BSA were co incubated at $60^{\circ} \mathrm{C}$ in the presence and absence of G. sylvestre. BSA was used to measure the antiglycation potential, and then fructosamine adducts, protein carbonyls, protein thiols, and congo red absorbance were calculated.

Table 1: Percentage inhibition of different glycated proteins by $G$. sylvestre

\begin{tabular}{|c|l|c|}
\hline S.No. & Parameters & Percentage inhibition \\
\hline 1. & Fructosamine & $36.22 \%$ \\
2. & Protein carbonyls & $15.56 \%$ \\
3. & Protein thiols & $67.84 \%$ \\
4. & Protein amyloids & Not found \\
\hline
\end{tabular}

The values represented are mean $\pm S E$, where $n=3$. 
In glycation inhibitory activity, methanolic extract of $G$. sylvestre showed remarkable results for antiglycation potential. For, determination of glycation potential, inhibition the various parameters were calculated like fructosamine inhibition was found to be 36.22 $\%$, protein carbonyls were inhibited up to $15.56 \%$, whereas protein thiols were inhibited up to $67.84 \%$. The glycation inhibitory potential was shown in Table 1.

Automated docking technique was utilized to determine the 'orientation' of dihydroxy gimnemic triacetate bound with the active pockets of $\alpha$-amylase, $\alpha$-glucosidase and aldose reductase enzyme, the interaction of dihydroxy gimnemic triacetate with the active pocket of enzymes were depicted in Figures 4, 5 and 6. Dihydroxy gimnemic triacetate demonstrated minimum binding energy with enzyme via non-covalent interaction (Table 2). These in silico observation substantiate the in vitro $\alpha$-amylase, $\alpha$-glucosidase and aldose reductase inhibitory activity of dihydroxy gimnemic triacetate.

The amino acids present in the active site of aldose reductase capable of interaction with dihydroxy gimnemic triacetate are found to be CYS A298, LYS A262, ILE A260, PRO A261, GLN A183, ASN A160, TYR A209, SER A214, HIS A110 and ASP A47. The amino acids responsible for the binding of $\alpha$-amylase and $\alpha$-glucosidase with dihydroxy gimnemic triacetate was identified as ARG A337, ALA A324, ASP A297, MET A 328, LEU A329, TYR A321, ILE A391, GLU A385, HIS A386, VAL A325, SER A340, PHE A315 and LYS A523, PHE A543, LYS A524, SER A544, ASP A546, TRP A581, LEU A323, GLU A322, respectively. The data obtained for aldose reductase, $\alpha$-amylase and $\alpha$-glucosidase interaction with dihydroxy gimnemic triacetate were illustrate as Figures 4, 5, 6 and Table 2.

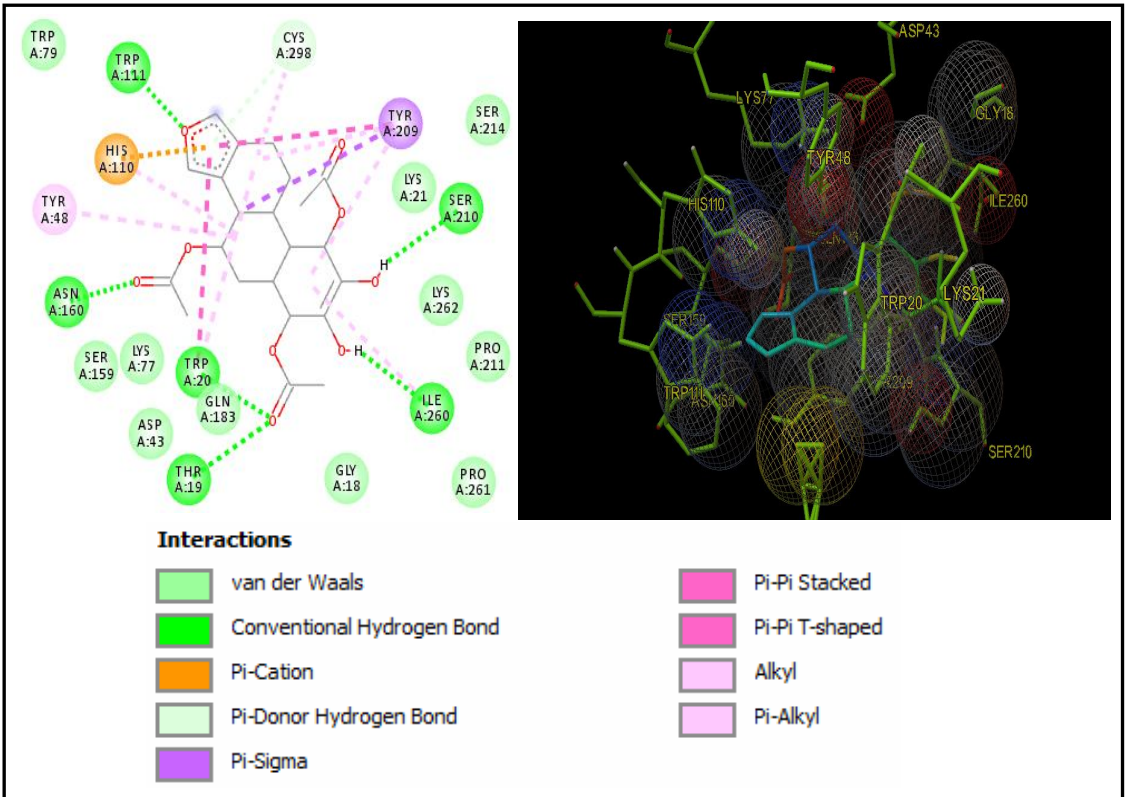

Figure 4: Molecular docking studies of dihydroxy gymnemic triacetate against aldose reductase.

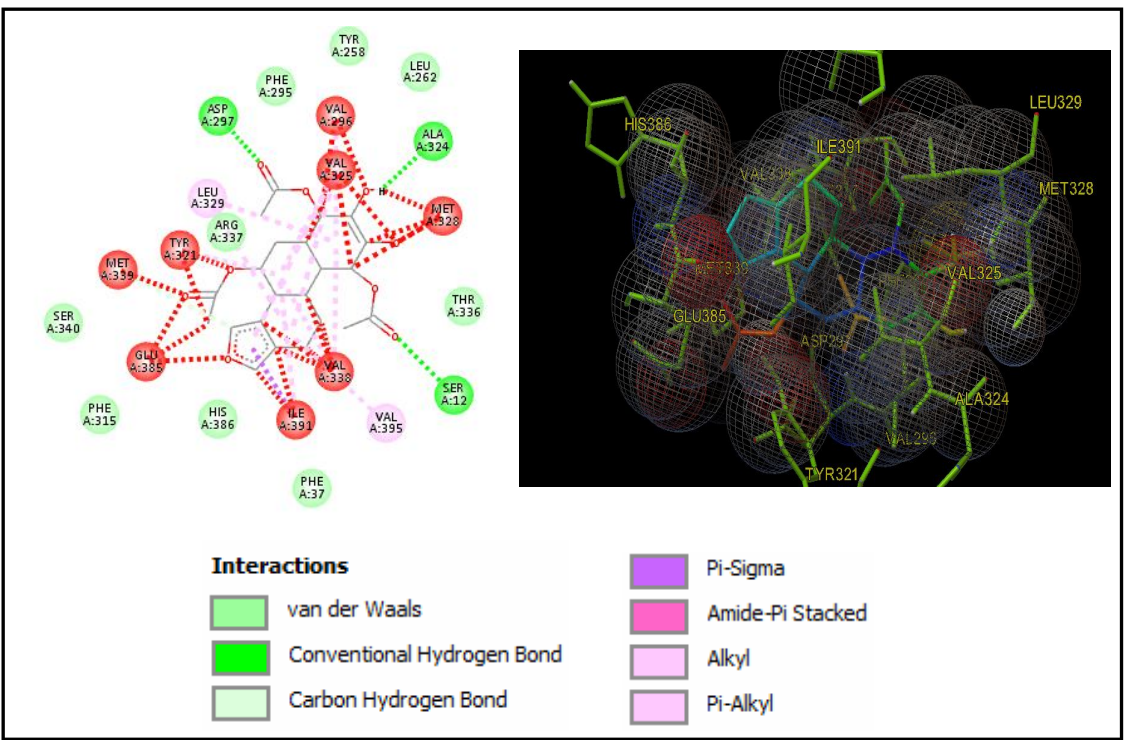

Figure 5: Molecular docking studies of dihydroxy gymnemic triacetate against $\alpha$-amylase. 


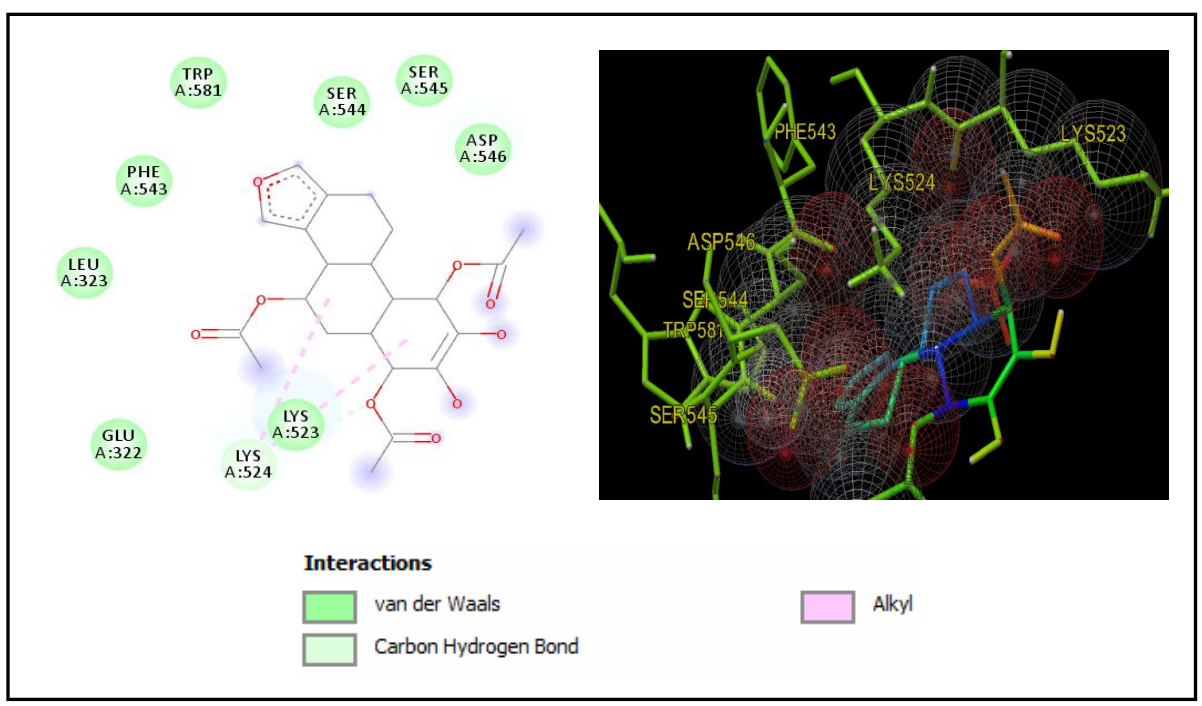

Figure 6: Molecular docking studies of dihydroxy gymnemic triacetate against $\alpha$-glucosidase.

Table 2: Molecular docking studies of dihydroxy gymnemic triacetate on $\alpha$-amylase, $\alpha$-glucosidase, and aldose reductase inhibitors

\begin{tabular}{|l|c|c|c|}
\hline Parameters & $\begin{array}{c}\text { Aldose } \\
\text { reductase }\end{array}$ & $\alpha$-glucosidase & $\alpha$-amylase \\
\hline Binding energy & -3.85 & -4.40 & -1.24 \\
$\begin{array}{l}\text { Inhibition } \\
\text { constant }(\mu \mathrm{m})\end{array}$ & 4.5 & 75.84 & 6.4 \\
$\begin{array}{l}\text { Intermolecular } \\
\text { energy }\end{array}$ & -6.24 & -6.79 & -5.48 \\
\hline
\end{tabular}

In the docking studies, the binding energy and intermolecular energy of the dihydroxy gimnemic triacetate was found to be $-3.85,-4.40$, -1.24 and $-6.24,-6.79,-5.48$ for aldose reductase, $\alpha$-glucosidase and $\alpha$-amylase enzyme, respectively. It is evidenced from the data obtained that the binding energy of dihydroxy gimnemic triacetate antidiabetic ligands possesses significant aldose reductase, $\alpha$-glucosidase and $\alpha$-amylase inhibitory activities.

\section{Discussion}

Diabetes, a chronic metabolic condition associated with hyperglycemia, caused by insufficient or inefficient insulin production, is currently a global problem. With over 68 million diabetes patients identified in India, the disease is quickly becoming a pandemic. According to ICMR report, diabetes is on the rise in India, particularly among persons of lower socio-economic status in metropolitan areas of economically developed states. According to published figures, India's diabetic population is anticipated to grow from 31.7 million in 2000 to 79.4 million in 2030 (Whiting et al., 2011). Diabetes can be readily prevented and controlled by increasing physical activity, reducing calorie intake, and avoiding sedentary behavior. However, altering one's lifestyle is difficult for many people, and they seek a less burdensome alternative.

Plants with sugar lowering effects have been used in traditional medicine for thousands of years without side effects. India is blessed with a large number of plants, which are used to treat diabetes. For ages, G. sylvestre has been utilised in Ayurvedic medicine in India to treat diabetes. Diabetes mellitus affects hundreds of million people worldwide (Shabana et al., 2015). Over five million deaths occurred in India due to complications associated with diabetes (Goh and Cooper, 2018). This creates an environment highly favorable to increasing protein damage caused by glycation. It has been seen that the inhibition of various glycolytic enzyme can turn as a remedy (Perera, 2016).

Oboh et al. (2015) found that inhibiting $\alpha$-amylase delays the digestion of starch while inhibiting $\alpha$-glucosidase hinders the digestion of disaccharides, making it an excellent tool for diabetes management by regulating and reducing the rise in postprandial glucose levels. Balaji et al. (2015) highlight the usefulness of natural sources of $\alpha$ amylase, $\alpha$-glucosidase and aldose reductase inhibitors in folk medicine for the treatment and control of diabetes.

In this present study, we investigated the $\alpha$-amylase, $\alpha$-glucosidase and aldose reductase inhibitory activity and glycation potential of G. sylvestre . It shows, G. sylvestre significantly inhibited $(p<0.001)$ activity of $\alpha$-amylase, $\alpha$-glucosidase and aldose reductase. Advanced glycation end products (AGEs) are thought to occur as a result of non-enzymatic glycation between decreasing sugar and protein, and they play a role in the pathophysiology of diabetes and ageing problems (Babu et al., 2004).

Docking studies confirmed the interaction of dihydroxy gimnemic triacetate with these enzymes. The docking analysis revealed that $\alpha$-amylase, $\alpha$-glucosidase, and aldose reductase have strong affinity to dihydroxy gimnemic triacetate. The phytochemicals exhibit improved binding sites, interactions, and a significant inhibitory effect on enzyme activity, according to a molecular docking research. According to Abdin et al. (2003), docking is frequently used to predict the affinity and activity of small molecule drug candidates by predicting their binding orientation to their protein targets. As a result, docking is quite important in the logic. 
Madeswaran et al. (2011): Lengauer and Rarey (1996) highlighted binding energy, inhibition constant, intermolecular energy, and phytochemical orientation with receptors in their investigation. These molecular docking indices are considered significant. Molecular docking, according to Bissantz et al. (2000) is a complicated process that comprises of two parts: ligand prediction and orientation, and affinity for the target.

\section{Conclusion}

In this study, the inhibitory action and antiglycation potential of critical enzymes such as $\alpha$-amylase, $\alpha$-glucosidase, and aldose reductase were investigated using a methanolic extract of $G$. sylvestre. It depicts the enzyme inhibitory and antiglycation potentials that are most prevalent. Based on the report, we may conclude that G. sylvestre extract contains herbal bioactive components with enzyme inhibitory ability. Docking studies verified the active components dihydroxy gimnemic triacetate found in G. sylvestre with this enzyme. This interaction demonstrates how well enzymes bind to dihydroxy gimnemic triacetate.

The findings suggest that the considerable antidiabetic characteristics of G. sylvestre and its phytochemicals are due to their inhibitory effects on $\alpha$-amylase, $\alpha$-glucosidase, and aldose reductase, as well as their antiglycation potential. The phytochemicals exhibit improved binding sites, interactions, and a significant inhibitory effect on enzyme activity, according to a molecular docking research.

\section{Conflict of interest}

The authors declare no conflicts of interest relevant to this article.

\section{References}

Abdin, M.Z; Israr, M.; Rehman, R.U. and Jain, S.K. (2003). Artemisinin, a novel antimalarial drug: Biochemical and molecular approaches for enhanced production. Planta Medica, 69(4):289-299.

Acharya, C.; Coop, A.; Polli, J.E. and Mackerell, A.D. (2011). Recent advances in ligand-based drug design: Relevance and utility of the conformationally sampled pharmacophore approach. Current Computer Aided Drug Design, 7:10-22.

Babu, S.K.; Tiwari, A.K.; Srinivas, P.V.; Ali, A.Z.; Raju, C.B. and Rao, J.M. (2004) Yeast and mammalian $\alpha$-glucosidase inhibitory constituents from Himalayan rhubarb Rheum emodi Wall. Ex Meisson. Bioorganic and Medicinal Chemistry Letter, 14(14):3841-3845.

Baker, J.R.; Zyzak, D.V.; Thorpe, S.R. and Baynes, J.W. (1994). Chemistry of the fructosamine assay: D-glucosone is the product of oxidation of Amadori compounds. Clinical Chemistry, 40(10):1950-1955.

Balaji, R.M.; Chitra Jeyaram, K.; Sundaram, M. and Ramasamy, M.S. (2015). Studies on antidiabetic activity of indian medicinal plants using amylase and glucosidase inhibitory activity: A pathway to antidiabetic drugs. World Journal of Medical Sciences, 12(3):207-212.

Bishayee, A. and Chatterjee, M. (1994). Hypolipidaemic and antiatheroscle rotic effects of oral Gymnema sylvestre $\mathrm{R}$. Br. leaf extract in albino rats fed on a high fat diet. Phytotherapy Research, 8(2): 118-120.

Bissantz, C.; Folkers, G. and Rognan, D. (2000). Protein-based virtual screening of chemical databases: Evaluation of different docking/scoring combinations. Journal of Medicinal Chemistry, 43(25):4759-4767.

David, B.C. and Sudarsanam, G. (2013). Antimicrobial activity of Gymnema sylvestre (Asclepiadaceae). Journal of Acute Disease, 2(3):222-225.

Davis, S.N. and Granner, D.K.(1996). Insulin. In: Goodman and Gilman's the Pharmacological Basis of Therapeutics, ninth ed., pp:1487-1517.
Ellman, G.L.(1959). Tissue sulfhydryl groups. Archives of Biochemistry and Biophysics, 82(1):70-77.

Genet, S.; Kale, R.K. and Baquer, N.Z. (2002). Alterations in antioxidant enzymes and oxidative damage in experimental diabetic rat tissues: Effect of vanadate and fenugreek (Trigonella foenum-graecum). Molecular and Cellular Biochemistry, 236(1):7-12.

Goh, S. and Cooper, M.E. (2008). The role of advanced glycation end products in progression and complications of diabetes. Journal of Clinical Endocrinology and Metabolism, 93(4):1143-1152.

Haraguchi , H.; Ohmi, I.; Fukuda, A.; Tamura, Y.; Mizutani, K.; Tanaka, O. and Chou, W.H. (1997). Inhibition of aldose reductase and sorbitol accumulation by astilbin and taxifolin dihydroflavonols in Engelhardtia chrysolepis. Bioscience, Biotechnology and Biochemistry, 61(4):651-654

Jeyachandran, R. and Mahesh, A. (2007). Antimicrobial evaluation of Kigelia africana (Lam). Research Journal of Microbiology, 2(8):645-649.

Kapoor, L.D. (1990). CRC handbook of Ayurvedic medicinal plants. Boca Raton: CRC Press, pp:200-201.

Kim, Y.M.; Jeong, Y.K.; Wang, M.H.; Lee, W.Y. and Rhee, H.I.(2005). Inhibitory effect of pine extract on alpha-glucosidase activity and postprandial hyperglycemia. Nutrition, 21(6):756-761.

Kiruthiga, N.; Saravanan, G.; Selvinthanuja, C.; Srinivasan, K. and Sivakumar,T. (2021). Glycolytic inhibition and antidiabetic activity on synthesized flavanone scaffolds with computer aided drug designing tools. Letters in Drug Design and Discovery, 18:574-592.

Klunk,W.E.; Jacob, R.F. and Mason, R.P. (1999). Quantifying amyloid by Congo red spectral shift assay. Methods in Enzymology, 309:285-305.

Kotowaroo, M.I.; Mahomoodally, F.M.; Fakim, F.G. and Subratty. (2006). Screening of traditional antidiabetic medicinal plants of Mauritius for possible alpha amylase inhibitory effects in vitro. Phytotherapy Research, 20(3):228-231.

Kurihara, Y. (1992). Characteristics of antisweet substances, sweet proteins and sweetness inducing protein. Critical Reviews in Food Science and Nutrition, 32(3):231-252.

Lalitha, V. and Sivakumar, T.(2018). Effect of silymarin on intestinal alkaline phosphatase level in a rat model of type 2 diabetes mellitus: Streptozotocin and high-fat diet treated wistar rats. Asian Journal of Pharmaceutical and Clinical Research, 11(11):304-306.

Lengauer, T. and Rarey, M. (1996). Computational methods for biomolecular docking. Current Opinion in Structural Biology, 6(3):402-406.

Madeswaran, A.; Umamaheswari, M.; Asokkumar, K.; Sivashanmugam, T.; Subhadradevi, V. and Jagannath, P. (2011).Docking studies: In silico lipoxygenase inhibitory activity of some commercially available flavonoids. Bangladesh Journal of Pharmacology, 6:133-138.

Mai, T.T. and Chuyen, N.V. (2007). Antihyperglycemic activity of an aqueous extract from flower buds of Cleistocalyx operculatus (Roxb.) Merr and Perry, Bioscience Biotechnology Biochemistry. 71(1):69-76.

McPherson, J.D.; Shilton, B.H. and Walton, D.J. (1988). Role of fructose in glycation and cross-linking of proteins. Biochemistry, 27(6):19011907.

Mhasker, KS. and Caius, JF. (1930). A study of Indian medicinal plants. II. Gymnema sylvestre R.Br. Indian Journal of Medical Research, 16: $2-75$.

Neerja, R.; Neha, V.; Devina, V. and Arti, G. (2017). Application of amylase producing bacteria isolated from hot spring water in food industry. Ann. of Phytomedicine., 6(2):93-100. 
Nupur, M.; Kaustubh, J.; Swati, R.; Sara, A.K. and Badal, P. (2019). In vitro evaluation of selected Indian spices for $\alpha$-amylase and $\alpha$-glucosidase inhibitory activities and their spice-drug interactions. Ann. of Phytomedicine., 8(2):43-54.

Oboh, G.; Akinbola, I.; Ademosun, A.; Sanni. D.; Odubanjo, O.; Olasehinde, T. and Oyeleye, S. (2015). Essential oil from clove bud (Eugenia aromatica Kuntze) inhibit key enzymes relevant to the management of type 2 diabetes and some prooxidant induced lipid peroxidation in rat pancreas in vitro. Journal of Oleo Science, 64(7):775-782

Patel, K. and Srinivasan, K. (1997). Plant foods in the management of diabetes mellitus: Vegetables as potential hypoglycemic agents. Nahrung, 41(2):68-74.

Perera, H.K. (2016). PAGE-a simple method to detect the protective effect of medicinal plants against sugar induced protein damage. Journal of The Natural Science Foundation of Sri Lanka, 44 (1):105-107.

Puratchimani, V. and Jha, S. (2004). Standardization of Gymnema sylvestre $\mathrm{R}$. Br. with reference to gymnemagenin by high-performance thinlayer chromatography. Phytochemical Analysis, 15:164-166.

Selvaraj, G.; Sathyavani, K.; Haja Sherief, S. and Ramanathan, T. (2014). Molecular docking, isolation and biological evaluation of Rhizophora mucronata flavonoids as anti-nociceptive agent. Biomedicine and Preventive Nutrition, 4(4):555-560.

Shabana, P.; Karishma, C. and Syed, A.H. (2015). Bioactive principles of Gymnema sylvestre R.Br. from yesterday's tradition to tomorrow's drug. Ann. of Phytomedicine., 4(2):18-33.

Shanmugasundaram, K.R.; Panneerselvam, C.; Samudram, P. and Shanmugasundaram, E.R. (1983). Enzyme changes and glucose utilization in diabetic rabbits: the effect of Gymnema sylvestre, R.Br. Journal of ethnopharmacology, 7(2):205-234.

Sofowora, A. (1982). Medicinal plants and traditional medicine in Africa 2nd Edn. Ibadan: John Willey and Sons ltd, pp:8-14.

Stocklin, W. (1969). Chemistry and physiological properties of gymnemic acid, the antisaccharine principle of the leaves of Gymnema sylvestre. Journal of Agricultural and Food Chemistry, 17:704708 .

Strojek, K. (2003). Features of macrovascular complications in type 2 diabetic patients. Acta Diabetologica, 40:334-337.

Sutedja, L. (2005). Bioassay of antidiabetes based on $\alpha$-glucosidase inhibitory activity. In: Functional Food Production Technology. 1st ed. Bioscience, Biotechnology and Biochemistry, pp:56-63.

Tiwari, B.K.; Pandey, K.B.; Abidi, A.B. and Rizvi, S.I. (2013). Therapeutic potential of Indian medicinal plants in diabetic condition. Ann. Phytomedicine., 2(1): 37-43.

Trott, O. and Olson, A.J. (2010). Auto dock vina: Improving the speed and accuracy of docking with a new scoring function, efficient optimization and multithreading. Journal of Computational Chemistry, 31(2):455-461.

Uchida, K.; Kanematsu, M.; Sakai, K.; Matsuda, T.; Hattori, N.; Mizuno, Y.; Suzuki, D.; Miyata, T.; Noguchi, N.; Niki, E. and Osawa, T. (1998). Protein-bound acrolein: Potential markers for oxidative stress. Proceedings of the Natural Academy of Sciences of the United State of America, 95(9):4882-4887.

Ueda, H.; Tachibana, Y.; Moriyasu, M.; Kawanishi, K. and Alves, S.M. (2001). Aldose reductase inhibitors from the fruits of Caesalpinia ferrea C. Mart. Phytomedicine, 8(5):377-381.

Wada, L. and Ou, B. (2002). Antioxidant activity and phenolic content of oregon cane berries. Journal of Agriculture and Food Chemistry, 50(12):3495-3500.

Whiting, D.R.; Guariguata, L.; Weil, C. and Shaw, J. (2011). IDF Diabetes Atlas: Global estimates of the prevalence of diabetes for 2011 and 2030. Diabetes Research and Clinical Practice, 94:311-321.

Yao, Y.; Sang, W.; Zhou, M. and Ren, G. (2010). Antioxidant and alpha glucosidase inhibitory activity of colored grains in China. Journal of Agriculture and Food Chemistry, 58(2):770-774. 